\title{
PROSPEK PENGEMBANGAN EKONOMI SYARIAH DI MASYARAKAT BANJAR KALIMANTAN SELATAN
}

\author{
Ahmadi Hasan \\ IAIN Antasari Banjarmasin \\ Jl. Jenderal Ahmad Yani Km.4,5, Banjarmasin \\ E-mail: ahmadihasan58@yahoo.com
}

\begin{abstract}
Economic Development Prospects of Sharia in the Banjar Society in South Kalimantan. Currently Islamic economics, with a wide range of variants, is developing widely and dynamically. The development of Islamic finance has been extended to almost all parts of Indonesia, both in urban and rural areas. The Banjar tribe are a sub-ethnic group that inhabit the South Kalimantan area originating from the Malay coast. Islam is the foundation of culture and identity of the community of the Banjar. The presence of the Islamic economic concept in Banjar society is no longer unusual because Islamic values associated with it have become common place. The development of Islamic economics in Banjar society will continue to flourish if supported by government policy (top-down approach).
\end{abstract}

Keywords: Islamic economics, behavioral economics, custom, custom trade

\begin{abstract}
Abstrak. Prospek Pengembangan Ekonomi Syariab di Masyarakat Banjar Kalimantan Selatan. Saat ini, ekonomi syariah, dengan pelbagai variannya, berkembang secara luas dan dinamis. Perkembangan ekonomi syariah sudah menjangkau hampir seluruh wilayah Indonesia, baik di perkotaan maupun pedesaan. Suku Banjar merupakan sub-etnis yang mendiami wilayah Kalimantan Selatan yang berasal dari Melayu Pesisir. Islam merupakan landasan budaya dan identitas komunitas orang Banjar. Kehadiran konsep ekonomi syariah di masyarakat Banjar merupakan hal yang tidak asing lagi karena nilai-nilai ajaran Islam yang berkaitan dengan hal tersebut sudah menjadi kebiasaan. Perkembangan ekonomi syariah di masyarakat Banjar akan semakin tumbuh apabila didukung dengan adanya kebijakan pemerintah (top down).
\end{abstract}

Kata Kunci: ekonomi syariah, perilaku ekonomi, adat, adat dagang

\section{Pendahuluan}

Membicarakan perilaku ekonomi atau adat dagang sebuah komunitas, apalagi yang berkaitan dengan orang Banjar, menarik untuk diulas mengingat beberapa hal, yaitu: pertama, perilaku ekonomi merupakan suatu refleksi atau kristalisasi dari perilaku atau budaya suatu komunitas atau kelompok etnis tertentu, termasuk dalam hal ini suku Banjar. Ia dapat pula diabstraksikan sebagai wujud dari etos kerja sebuah kelompok. Etos kerja terkadang dipengaruhi oleh paham keagamaan yang dianut oleh sekelompok penganut agama tertentu. ${ }^{1}$

Kedua, apakah orang Banjar merupakan rumpun asli

Naskah diterima: 20 Februari 2014, direvisi: 25 Maret 2014, disetujui untuk terbit: 30 Mei 2014.

${ }^{1}$ Tesis Max Weber tentang apa yang disebutnya dengan "Etika Protestan" dan hubungannya dengan "Semangat Kapitalisme" (The Spiirit of Capitalism) yang kemudian dikenal dengan teori etos kerja, yang menjadi acuan teoritis di kalangan sosiolog-antropolog dalam melihat relasi agama terhadap perilaku ekonomi seseorang. Ajat Sudrajat, Etika Protestan dan Kapitalisme Barat, Relevansinya dengan Islam Indonesia, (Jakarta: Bumi Aksara, 1994), h. 194. komunitas yang ada di Kalimantan dan memberikan pengaruh secara dominan terhadap perilaku orangorang yang mendiami kawasan yang dahulu dikuasai oleh kerajaan Banjar, atau justeru Banjar hanya merupakan sub-etnis dari keseluruhan budaya orangorang yang ada di Kalimantan Selatan.

Ketiga, apakah benar Islam merupakan keyakinan yang memberikan pengaruh terhadap etos kerja orang Banjar, yang dalam hal ini juga memberikan justifikasi terhadap budaya atau adat dagang orang Banjar. Tulisan ini berupaya mengungkap seberapa besar sumbangan Islam, dalam hal ini mazhab Syâfî̀ dan relevansinya dalam memberikan pengaruh terhadap pembentukan pola hidup dan etos kerja atau adat dagang orang Banjar di Kalimantan Selatan dan bagaimana kaitannya dengan faktor perkembangan sektor ekonomi syariah yang semakin meningkat saat ini.

\section{Karakteristik Orang Banjar}

Banyak tulisan mengenai etnis Banjar yang menyangkut asal usul dan apa yang mempengaruhi adat 
istiadat mereka, misalnya mulai dari karya orang luar Indonesia seperti: (1) J.J. Ras yang berjudul "Hikayat Banjar, a Study in Malay Histories". (2) J. Eisenberger yang berjudul "Kroniek der Zuider-en Oosterafdeeling van Borneo". (3) Mallincrodt yang berjudul "Het Adatrecht van Borneo, AM Joekes, De Wet van Sultan Adam van Bandjermasin van 1835 dalam De Indische Gids". Begitu juga tulisan dari dalam Indonesia sendiri, seperti: (1) Alfani Daud yang berjudul "Islam dan Masyarakat Banjar". (2) Edwar Saleh mengenai "Lukisan Perang Banjar" dan "Sekilas mengenai Daerah Banjar dan Kebudayaan Sungainya sampai Akhir Abad ke-19". (3) Gazali Usman mengenai "Urang Banjar dalam Sejarah". (4) Taufik Arbain yang berjudul "Migrasi Orang Banjar di Kalimantan Tengah". Dan masih banyak lagi penulis lain yang pada umumnya membahas tentang bagaimana asal usul orang Banjar dan pola interaksi mereka dengan masyarakat sekitar. Ada tesis yang mengatakan bahwa orang Banjar itu berasal dari Melayu pesisir dan budayanya pun adalah budaya Melayu. Kemudian ada pula tesis yang mengatakan bahwa menjadi Banjar berarti berislamnya suku bangsa yang mendiami teluk raksasa selatan Borneo.

Menurut Mallinkrodt, suku Banjar adalah suatu namayang diberikan untuk menyebutsuku-sukuMelayu terutama yang berasal dari daerah penguasaan Hindu Jawa yang sebagian besar berdiam di pesisir Kalimantan Selatan, Tengah, Timur, dan Barat. ${ }^{2}$ Menurut J.J. Ras, konsentrasi koloni Melayu yang pertama terdapat di daerah Tabalong, yang kemudian berkembang menjadi suku Banjar. Mereka ini bermigrasi dari Indonesia Barat pada permulaan abad pertama Masehi. ${ }^{3}$ Mereka memasuki bagian timur Teluk Besar dengan lerenglereng kaki pegunungan Meratus sebagai pantainya, danau daratan rendahnya, yang kemudian disebut Banua Lima dan Banua Lawas. Dalam wilayah tua inilah golongan melayu ini berbaur dengan kelompok Olo Maanyan dan orang-orang Bukit, menelurkan inti pertama suku Banjar, mendirikan kerajaan Tanjung Pura dengan ibu kota Tanjung Puri yang mungkin sekali terletak di sekitar Tanjung sekarang. ${ }^{4}$

Jika dikaitan dengan pembagian 19 wilayah hukum adat versi Van Vollenhoven, asal usul suku Banjar tidak selalu tepat. Di dalam menyusun klasifikasi lingkungan hukum adat Kalimantan Selatan (Banjar) terdapat bias, karena ternyata Van Vollenhoven terpengaruh

${ }^{2}$ Mallinkordt, Het Adaatrecht van Boerneo, (Leiden: J.E. Brill, 1928), h. 48.

${ }^{3}$ M. Idwar Saleh, Banjarmasin Sejarah Singkat mengenai Bangkit dan Berkembangnya Kota Banjarmasin serta Wilayah sekitarnya sampai dengan tahun 1950, Naskah tidak dipublikasikan, 1975, h. 13.

${ }^{4}$ M. Idwar Saleh, Banjarmasin Sejarah Singkat, h. 14. oleh pendapat para sarjana bahasa. ${ }^{5}$ Karenanya, secara etnisitas, orang Banjar dari segi asal usul tidak dipahami betul oleh Van Vollenhoven sehingga ia memasukkan ke dalam Melayu Sumatera (adatrechtkring). Padahal orang Banjar memiliki karakteristik yang cukup unik. Dalam hal ini, pendapat Mallinckrod ada benarnya. Memang secara etnis orang Banjar lebih dekat dengan Melayu, ${ }^{6}$ namun tidak berarti lingkungan hukum adatnya juga Melayu, sebab Kabupaten Kotabaru tidak termasuk wilayah hukum adat Banjar, tetapi kabupaten Hulu Sungai justeru termasuk kategori lingkungan adat Dayak. Boleh jadi telah terjadi percampuran (asimilasi antara Melayu, Dayak, dan sebagainya) sehingga kajian ini perlu dikembangkan lebih lanjut.

Lebih jauh dapat dikemukakan bahwa kebiasan masyarakat yang disebutkan sebagai "adat", "adat kebiasaan", atau "adat istiadat" sangat sulit untuk dibedakan dari hukum adat, sehingga secara konsepsional, hukum adat tidak dapat ditempatkan secara tegas dari adat istiadat tersebut. Begitu juga dalam kaitannya dengan hukum agama, mengingat sebagian besar dan ketentuan hukum agama dalam persepsi masyarakat sudah berbaur dengan hukum adat setempat, sehingga akan ditemukan ada pranata yang dianggap sebagai pranata agama, akan tetapi kalau ditinjau dari segi ajaran agama Islam berdasarkan ajaran Alquran dan Hadis, hal ini bukan merupakan bagian dari ajaran agama. Ratno Lukito menyatakan bahwa antara hukum Islam dan hukum adat merupakan dua sistem yang berbeda, namun tidak perlu dipertentangkan. Dalam kaitannya dengan prospek ke depan, bagaimana melakukan harmonisasi antar sistem hukum, baik antara hukum Barat, hukum Islam, maupun hukum adat. $^{7}$

Hukum Islam yang berlaku untuk sebagian besar masyarakat dipengaruhi oleh Mazhab Syâfi'î. Hal ini juga dinyatakan dengan tegas dalam UndangUndang Sultan Adam (1835), terutama untuk bidang perkawinan. ${ }^{8}$

${ }^{5}$ Soerjono Soekanto, Kedudukan dan Peranan Hukum Adat di Indonesia, (Jakarta: Kurnia Esa, 1970), h. 55.

${ }^{6}$ Menurut Soeryono Soekanto, di Kalimantan terdapat 73 suku atau etnis termasuk suku Banjar Melayu pesisir. Soerjono Soekanto, Hukum Adat Indonesia, (Jakarta: Rajawali Press, 1983), h. 23. Tentang Pembagian Wilayah Hukum Adat pada Bagian ke 5 Tanah Melayu (Lingga-Riau, Indragiri, Sumatera Timur, Orang Banjar), lihat Bushar Muhammad, Asas-Asas Hukum Adat, Sebuah Pengantar, (Jakarta: Pradnya Paramitha, 2002), h. 94 dan B. Ter Haar, Asas-Asas Hukum Adat, (Jakarta: Pradnya Paramitha, 1999), h. 34.

Ratno Lukito, Pergulatan Hukum Islam dan Hukum Adat, (Jakarta: Inis, 1998).

${ }^{8}$ Dalam praktek ternyata ditemukan juga pengaruh dari mazhab lain seperti dalam upacara kematian dikenal acara bahelah yang mereka ambil dari Mazhab ㅌanafî. Hal ini menunjukkan bahwa sebagian besar 
Aplikasi Hukum Islam cukup terasa melalui peranan para alim ulama. Selain itu, sejak zaman dahulu telah dikenal pejabat Agama yang dinamakan Mufti dan Kadi, yang semula merupakan pejabat dalam struktur kerajaan untuk menjalankan fungsi peradilan. Akan tetapi walaupun Kerajaan Banjar sudah dihapuskan pada tahun 1860, namun kedudukan mufti dan kadi dalam masyarakat masih tetap dominan sampai dengan berdirinya Negara Kesatuan Republik Indonesia seperti sebutan "Surgi Mufti” dan "Tuan Kadi”.

Pemerintah Belanda sendiri tetap mempertahankan peranan kadi dengan dibentuknya Kerapatan Kadi dan Kerapatan Kadi Besar berdasarkan Stb 1937 No. 638 dan 639 sebagai salah satu bentuk peradilan agama Islam, khususnya untuk daerah ini, yang berbeda dengan daerah lainnya. Nama Kerapatan Kadi ini masih tetap dipertahankan terus sampai tahun 1975 ketika pemerintah menyelenggarakan penyeragaman nama pengadilan-pengadilan agama di Indonesia hanya dengan satu nama yaitu Pengadilan Agama. Namun Stb 1937 No. 638 dan 639 tetap berlaku terus sampai dengan dicabutnya berdasarkan Undang-Undang No. 7 tahun 1989 tentang Peradilan Agama. Untuk daerah Kalimantan Selatan, peranan kadi (dulunya juga mufti) besar sekali dalam pembinaan dan pengembangan hukum. ${ }^{9}$

Selain mufti, kadi juga sangat besar peranannya dalam pengembangan hukum di daerah ini, begitu juga dengan penghulu, ${ }^{10}$ yang pada saat sekarang peranannya hanya untuk mengawinkan dan melakukan pencatatan perkawinan. Jabatan ini diperkirakan jabatan yang baru tumbuh kemudian karena sama sekali tidak disebutkan dalam Undang-Undang Sultan Adam (1835). Walaupun ia hanya sekedar petugas pembantu Pejabat Pencatat Perkawinan dan sebelumnya ia bertugas sebagai P3NTR (Pegawai Pembantu Pencatat Nikah, Talak, dan Rujuk), bagi masyarakat ia juga berfungsi sebagai

ulama juga cukup terbuka dalam menerima faham mazhab lain dalam pelaksanaan hukum. Tim Peneliti, Mazhab Fikih yang Berkembang di Kalimantan Selatan, Fakultas Syari'ah, IAIN Antasari, Banjarmasin, 1990.

${ }^{9}$ Abdurrahman, Menggagas Format Baru Peranan Peradilan Agama Pasca Lahirnya UU No. 3 Tahun 2006 tentang Peradilan Agama, makalah disajikan dalam Seminar tentang Peranan Peradilan Agama Pasca Lahirnya UU No. 3 tahun 2006 pada tanggal 18 September 2006 di Fakultas Syariah IAIN Antasari Banjarmasin.

${ }^{10}$ Penghulu dalam kedudukannya sekarang adalah sebagai Pegawai Pencatat Nikah (PPPN) berkedudukan di bawah Kantor Urusan Agama (KUA) Kecamatan yang merupakan Pejabat Pencatatan Nikah (PPN) yang oleh masyarakat lebih dikenal dengan sebutan "naib" dalam praktiknya cukup berperan walaupun tidak sebesar penghulu karena pelaksanaan tugasnya secara tidak langsung berhubungan dengan masyarakat. Ahmadi Hasan, Adat Badamai Interaksi Hukum Islam dengan Hukum Adat pada Masyarakat Banjar, (Banjarmasin: Antasari Press, 2007), h. 145. pemuka masyarakat dan tokoh agama yang kadangkadang diminta pendapat dalam pemecahan masalahmasalah hukum tertentu, termasuk dalam penyelesaian hukum (badamai). ${ }^{11}$

Selain itu, dalam masyarakat Banjar, terutama sekali untuk bidang-bidang tertentu yang sudah secara tegas dibuat ketentuan hukum tertulisnya, dalam kenyataan hukum tertentu lebih dominan pengaruhnya seperti Undang-Undang No.5 tahun 1960 untuk bidang Pertanahan, Undang-Undang No. 1 Tahun 1974 untuk bidang Perkawinan, dan Undang-Undang No. 30 Tahun 1999 tentang Alternative Dispute Resulation (ADR) atau penyelesaian sengketa di luar pengadilan dengan jalan damai.

\section{Etos Kerja Orang Banjar}

Orang Banjar adalah orang yang hidupnya mengelompok dalam sebuah perkampungan. Perkampungan orang Banjar berderet di tepi sungai yang oleh para ahli disebut perkampungan Banjar. Artinya, perkampungan yang berderet-deret atau berjejer di tepi pantai. Sejak dahulu, orang Banjar tidak asing dengan budaya sungai. Sungai merupakan urat nadi kehidupan dan alat tranportasi utama. ${ }^{12}$

Kehidupan ekonomi orang Banjar pada waktu dahulu erat kaitannya dengan keadaan alam. Mereka hidup di tepi sungai dan melakukan kegiatan perekonomian dengan menggunakan sungai sebagai sarana utama. Dalam sejarah, sejak dahulu pedagang Banjar mengarungi pelosok sungai Martapura, Barito, Kahayan, Kapuas dan anak-anak sungainya seperti Sungai Negara, Alabio, Babirik, dan lain-lain, sampai ke pedalaman Kalimantan Selatan dan Tengah dalam rangka membawa dagangan berupa sembako (pangan), sandang dan papan untuk keperluan hidup masyarakat

\footnotetext{
${ }^{11}$ Sekalipun pejabat-pejabat tersebut tidak secara langsung berkenaan dengan hukum adat, tetapi sebagai petugas yang diserahi kewajiban melaksanakan hukum Islam, dalam kenyataan secara tidak langsung juga mempunyai peranan melakukan pembinaan terhadap hukum yang hidup dalam masyarakat. Hal ini juga menunjukkan bahwa antar hukum Islam dan adat di daerah Kalimantan Selatan tidak bisa dipisahkan secara tegas karena antara keduanya sudah berbaur satu dengan lainnya. Ahmadi Hasan, Adat Badamai Interaksi Hukum Islam dengan Hukum Adat pada Masyarakat Banjar, h. 156.

${ }^{12}$ Sejak masuknya arus modernisasi pada dasawarsa terakhir melalui pembangunan lima tahunan yang dicanangkan pemerintah Orde Baru, masyarakat Banjar juga menyesuaikan pola kehidupan dari budaya sungai pada budaya darat, menyusul dibangunnya inpra dan supra struktural, termasuk pembangunan jalan sampai ke pelosok-pelokos desa dan kampung. Sehingga dari segi lingkungan sungai hampir tidak pernah diperhatikan penanganannya. Lihat Data Pembangunan Perkotaan pada Pemerintah Kota Banjarmasin, tahun 2000.
} 
di pedalaman. ${ }^{13}$ Dengan menggunakan perahu besar bermesin, mereka memasarkan barang dagangan selama berbulan-bulan lamanya, disertai keluarga, anak, dan isteri. Ketika singgah di sebuah perkampungan, mereka berinteraksi sambil berdagang. Di sekitar kampung yang dikunjungi terkadang terbentuk koloni atau perkampungan orang Banjar. Terkadang tidak jarang diikuti dengan misi dakwah Islam di tengah masyarakat Dayak. Orang Banjar sejak dahulu dikenal menguasai sentra perdagangan atau pasar di pelbagai pelosok daerah, seperti Sampit, Kuala Pambuang, Pangkalan Bun, Muara Teweh, Puruk Cahu, dan sebagainya.

Setelah dari pedalaman, mereka labuh (kembali) ke Banjarmasin membawa hasil hutan, seperti rotan, damar, karet, dan sebagainya. Dari Banjarmasin, sebagai pusat perdagangan, hasil hutan itu kemudian dipasarkan ke pulau Jawa, bahkan sampai manca negara. Namun seiring dengan menguatnya arus globalisasi dan modernisasi seperti saat ini, budaya sungai sebagai sarana kegiatan ekonomi secara berangsur-angsur sudah berubah mengikuti perkembangan modernitas hampir di segala bidang, tidak hanya dalam aspek ekonomi.

Menurut beberapa peneliti, orang Banjar termasuk etnis perantau, tidak saja di daerah kawasan Nusantara, tetapi mereka merantau (madam) sampai ke daerah Timur Tengah dalam rangka memenuhi hajat untuk ibadah ke tanah suci. ${ }^{14}$ Taufik Arbain ${ }^{15}$ mengungkapkan bahwa budaya madam orang Banjar adalah dalam upaya memenuhi hajat dan naluri dagangnya. Orang-orang Banjar Pahuluan dengan gigih menelusuri sungaisungai Martapura dan Barito sampai ke daerah-daerah Sampit, Tembilahan, Sapat di Sumatera, Camplungan di Jawa Timur, dan daerah-daerah lainnya.

Apabila diperhatikan, dari beberapa kenyataan tersebut, setidaknya dapat digambarkan bahwa orang Banjar termasuk etnis pekerja keras, tangguh, ulet, serta gigih (cangkal) dalam berusaha (dagang). Hal ini

${ }^{13}$ Taufik Arbain, Strategi Adaptasi Migrasi Banjar di Palangka Raya Pasca Konflik Dayak-Madura Kalimantan Tengah, Tesis Program Pasca Sarjana Universitas Gajah Mada Yogyakarta, Maret, 2004, h. 94. dan J. Jahmin, Lada, Raja dan Pedagang (Perdagangan di Banjarmasin Medio abad 17), Tesis, Sastra Sejarah UGM Yogyakarta, 1991, h. 49.

${ }^{14}$ Jamaah haji turis dari Kalimantan Selatan khususnya, dan Indonesia pada umumnya, terus ada mengingat keterbatasan kuota jamaah haji yang dibatasi oleh Pemerintah Arab Saudi, sehingga selain melalui pelaksanaan umrah yang juga semakin meningkat, haji turis ini pun sejak puluhan tahun yang lalu merupakan solusi meskipun mereka menghadapi risiko diuber-uber oleh pemerintah Arab Saudi, kecuali mereka nekad mengurus iqâmah dan sebagainya. Hal ini sudah marak dilakukan, disamping sebagai solusi keterbatasan kuota, mungkin juga ada alasan lain, yakni adanya usaha ibadah haji sambil berdagang.

15 Taufik Arbain, Migrasi Orang Banjar di daerah Kalimantan Tengah, Program Kependudukan Universitas Gajah Mada, Yogyakarta, tahun 2003. merupakan gambaran etos kerja yang mereka anut, yaitu bahwa hidup adalah untuk berusaha yang kelak akan berimplikasi dalam kehidupan akhirat. Hal ini agak berbeda dengan hasil penelitian LIPI tahun 80-an, yang mengatakan bahwa etos kerja orang Banjar itu sangat individual kompetitif. Jika dikaitkan dengan pendapat Zurkani Yahya cukup relevan, bahwa rendahnya rasionalitas dalam perilaku ekonomi menjadikan etos kerja yang tinggi tidak banyak berfungsi. Hal ini, menurut Zurkani, disebabkan rendahnya rasionalitas dalam perilaku seseorang. Inklusif perilaku disebabkan oleh pemahaman yang kurang benar terhadap suatu ajaran agama teologi.

Pada satu sisi, orang Banjar berbeda dengan suku lainnya, yaitu bahwa nilai-nilai yang dikemukakan dari hasil penelitian tersebut menggambarkan orang Banjar tidak pernah maju bersama, sehingga kalau pun sukses merupakan jerih payah dan hasil keringat sendiri secara individual. Sukses dalam perantauan merupakan buah kerja keras dan kecangkalan (kegigihan) berusaha secara individual. Karena tantangan yang dihadapi demikian keras, mungkin ada juga pengaruh nilai-nilai budaya yang juga dipengaruhi oleh faktor geografis. ${ }^{16}$ Namun pada satu sisi, hal ini dapat dimaknai bahwa disamping memiliki nilai-nilai positif, dalam arti semangat ajaran agama, membuat orang Banjar termasuk pekerja keras, ulet (cangkal), tetapi juga jujur dan memegang prinsipprinsip ajaran agama, serta mereka sangat berhati-hati. Apalagi menyangkut nilai-nilai sakral yang terdapat dalam ajaran fikih dari tuan guru.

Menurut para pakar, sejak berabad-abad yang lalu, masyarakat Banjar selalu diidentikkan dengan Islam. ${ }^{17}$ Identifikasi masyarakat Banjar dengan Islam ini tidak lain merupakan bentuk identitas sosial yang merefleksikan suatu dasar ikatan sosial bersama. Secara historis, masyarakat Banjar selalu diidentikkan dengan Islam. Hal ini mencerminkan Islam sebagai suatu sistem yang dijadikan pegangan oleh masyarakat

16 Pada satu sisi, orang Banjar sangat dimanjakan oleh alam yang cukup melimpah. Dahulu orang Banjar terkenal dengan alam agrarisnya (pertanian dan perkebunan) sehingga menyebabkan mereka malas berinovasi dan berkreasi. Dalam memenuhi kebutuhan hidupnya, mereka tidak dituntut kerja keras karena semua keperluan tersedia dari alam yang melimpah. Namun seiring dengan hadirnya industrialisasi dan modernisasi yang mengakibatkan dampak terhadap kerusakan lingkungan, dampak itu ikut mengubah pola pandang masyarakatnya. Mereka tidak dapat mengandalkan kekayaan alam tanpa berusaha untuk melestarikannya untuk kepentingan generasi mendatang. Lesley Potter, Banjarese in and beyond Hulu Sungai, South Kalimantan a study of cultural independence, economic opportunity and mobility in New Challenges in The Modern Economic History Of Indonesia, Edited by J. Thomas Lindblad, Programme of Iindonesian Studies Leiden, 1993.

${ }^{17}$ Alfani Daud, Islam dan Masyarakat Banjar: Deskripsi dan Analisa Kebudayaan Banjar, (Jakarta: Raja Grafindo Persada,1997), h. 4. 
Banjar. Artinya, dalam banyak hal, perilaku-perilaku orang Banjar dapat dicarikan sumbernya pada nilai yang bersifat Islami. Dari kecenderungan sumber referensi perilaku sosial inilah maka fungsi keberislaman oleh masyarakat Banjar akhirnya menjadi simbol dan identitas yang membedakan mereka dengan kelompokkelompok masyarakat lain di sekitarnya. ${ }^{18}$ Dalam seluruh aspek kehidupan, terutama dalam masalah ibadah, fikih yang dianut adalah Mazhab Syâfî̀. Orang Banjar merupakan penganut Syâfi'iyyah yang fanatik. Fanatisme ini terefleksi dalam seluruh aspek kehidupan orang Banjar. Dalam adat dagang, orang Banjar sangat berpegang teguh dengan ajaran Syâf'î. Mazhab ini dapat dikatakan sudah mengkristal dan merupakan adat yang dapat dijadikan sebagai landasan dalam kehidupan orang Banjar.

\section{Perilaku Ekonomi (Adat Dagang) Orang Banjar}

Perilaku ekonomi, dalam hal ini adat dagang, orang Banjar sangat dipengaruhi oleh keadaan alam (geografis) dan agraris. Orang Banjar akrab dengan sungai dan pertanian. Pedagang Banjar yang terdiri atas antara lain orang Negara dan Alabio berdagang memanfaatkan sungai dan perahu besar bermotor dalam berdagang sampai ke daerah pedalaman. Melalui sarana perdagangan ini pula terbentuk transmisi nilai budaya yang dipengaruhi oleh etos kerja. Etos kerja orang Banjar sangat dipengaruhi oleh paham keberagamaan (Islam). ${ }^{19}$ Dalam kajian fikih muamalah, sahnya transaksi dipengaruhi oleh beberapa unsur, yaitu: (1) Adanya sighhat akad (pernyataan untuk mengikatkan diri). (2) Al-máqûd 'alayh/mahal al'aqd (objek akad). (3) Al-mutââqidaynlal-âqidayn (pihak-pihak yang berakad). (4) Mawdhû' al-'aqd (tujuan akad). ${ }^{20}$

Secara simbolik, adat dagang orang Banjar dapat dilihat bagaimana mereka memaknai akad sebagai sesuatu yang sangat signifikan. Mereka menganggap tidak sah suatu transaksi jual beli atau kegiatan dagang kalau akad tidak dilakukan dengan cara sempurna, misalnya, seorang penjual akan mengakadkan kepada pembeli dengan lafaz akad sebagai berikut, "Ulun jual kain tetoron sebanyak tiga meter dengan harga Rp. 36.000,-“ dan dijawab oleh pembeli seketika itu juga dengan ucapan akad "Ulun tukar 3 meter kain

${ }^{18}$ Alfani Daud, Islam dan Masyarakat Banjar: Deskripsi dan Analisa Kebudayaan Banjar, h. 4.

${ }^{19}$ Ajat Sudrajat, Etika Protestan dan Kapitalisme Barat, Relevansinya dengan Islam Indonesia, h. 194.

${ }^{20}$ Frank F. Vogel and Samuel L. Hayes, Islamic Law and Finance Religion, Risk, and Return, (London: Kluwer Law International, 1998), h. 222 dan Suhrawardi K. Lubis, Hukum Ekonomi Islam, (Jakarta: Sinar Grafika, 2000), h. 129-130. tetoron ini dengan harga Rp. 36.000,-. tunai”. Padahal ketika mereka berbelanja ke mall atau pasar swalayan, hal semacam itu tidak mungkin dilaksanakan secara sempurna. Kebiasaan yang mereka ucapkan adalah ucapan "terima kasih", "ya kembali", atau "ya terima kasih". Disamping itu, kedudukan kasir hanyalah wakil dari pemilik barang. Dalam perkembangan ekonomi bisnis seperti yang terjadi di pasar swalayan, maka ketika seseorang memilih suatu barang berarti menunjukkan persetujuannya untuk melakukan transaksi. Dalam Mazhab Hanafî, akad tidak mesti diikrarkan secara simbolik. Syarat 'an tarâdhin sudah terpenuhi ketika orang memilih barang.

Termasuk dalam hal ini adalah kebiasaan di kampung-kampung, dimana orang menyandakan barang, sawah/kebun, atau rumah kepada seseorang. Akad yang diucapkan adalah akad sanda. Tetapi yang populer, hal ini dikenal dengan istilah "jual hidup" untuk menyebutkan istilah sanda. Akad yang biasa diucapkan seseorang biasanya adalah "Ulun sandakan rumah ini kepada sampean sebesar lima juta rupiah untuk jangka waktu dua tahun". Dijawab oleh yang menerima dengan ucapan "Ulun sandai rumah ini sebesar lima juta rupiah untuk jangka waktu dua tahun". Hal ini disebut dengan jual hidup, sebab si penyanda hanya menguasai barang atau rumah tersebut selama jangka waktu tertentu. Setelah ditebus kembali atau dibayar kembali oleh si empunya, maka barang itu kembali menjadi milik si pemilik asal.

Ada lagi kebiasaan atau praktek seseorang menyandakan sebuah rumah kepada seseorang dengan harga yang disepakati. Tetapi kemudian rumah itu tetap dihuninya dengan konpensasi setiap bulan membayar uang kontrak kepada yang penerima sanda.

Sebenarnya kasus ini erat kaitannya dengan pinjam meminjam, namun dalam hal ini pinjaman dengan jalan agunan. Jadi dapat dimaknai seseorang perlu pinjaman kepada orang lain dengan jaminan rumah, yang kemudian disewanya kembali kepada yang memberikan pinjaman.

Tetapi ada juga kebiasaan atau adat yang justeru berakibat hukum di kemudian hari. Ada kebiasaan orang Banjar mewakafkan peruntukan tanah wakaf kepada nadzir, dalam hal ini panitia pembangunan langgar/ mushalla/mesjid. Tetapi pelaksanaan atau penyerahan peruntukan tanah wakaf itu hanya diikrarkan secara lisan. Padahal secara akad, praktek seperti itu sudah memenuhi rukun dan syarat sah terjadinya wakaf. Jika di kemudian hari harga jual tanah secara ekonomis meningkat, tidak jarang menimbulkan sengketa antara ahli waris dengan nadzir. Hal ini disebabkan tidak 
ada dokumen atau tanda bukti ikrar terjadinya wakaf terhadap peruntukan tanah wakaf. Kebiasaan seperti ini merupakan kebiasaan atau adat yang pada satu sisi bertentangan dengan nilai-nilai ajaran Islam. Islam mengajarkan agar mencatat setiap transaksi untuk menghindari sengketa di kemudian hari.

Hasil penelitian Adijani Al-Alabij dan yang lainnya sekitar tahun 1999 dengan topik sengketa tanah wakaf di Kalimantan Selatan menyebutkan bahwa problem sengketa tanah wakaf disebabkan karena pelaksanaannya masih secara tradisional. Prakteknya, ikrar wakaf itu tidak pernah langsung dibuatkan sertifikasinya oleh petugas karena tidak dilaporkan kepada petugas, walaupun secara rukun dan syarat masih memenuhi prinsip-prinsip aturan sahnya suatu perbuatan dari wâqif. Namun memang tidak ada keharusan ikrar itu dicatat, sebab pada saat terjadinya ikrar masingmasing pihak telah setuju dan beriktikad baik untuk sama-sama menunaikan kewajiban ibadah wakaf. Ke depan, kekurangan praktek pelaksanaan wakaf harus ditindaklanjuti dengan upaya sertifikasi tanah wakaf.

Faktor-faktor tersebut menyebabkan terjadinya sengketa tanah wakaf di kemudian hari. Dari data penelitian itu ada yang dapat diselesaikan secara kekeluargaan (damai), tetapi sebagian besar penyelesaian melalui lembaga peradilan (pengadilan negeri). Ada yang selesai pada tingkat pertama di pengadilan negeri, tetapi ada beberapa kasus yang proses perkaranya tidak selesai kecuali sampai di tingkat kasasi di Mahkamah Agung. ${ }^{21}$

\section{Perilaku Ekonomi Orang Banjar dan Kehadiran Ekonomi Syariah}

Kehadiran konsep ekonomi syariah pada masyarakat Banjar sebenarnya tidak asing lagi, mengingat nilai-nilai ajaran Islam yang berkaitan dengan prinsip-prinsip dagang atau muamalat sudah sangat akrab dengan budaya Banjar. Hanya saja kehadiran ekonomi syariah yang dipaksakan dari atas (top down) nampaknya sangat relevan dengan adat atau budaya dagang orang Banjar. Gerakan kehidupan dagang atau ekonomi berbasis Islam nampaknya sudah memasyarakat dan tumbuh dari bawah (bottom up) pada masyarakat Banjar. Masalahnya adalah seberapa besar adat dagang orang Banjar ini memberikan kontribusi atau sumbangsih dalam perkembangan konsep ekonomi syariah.

Di Indonesia, ekonomi Islam dikenal dengan nama ekonomi syariah, keuangan syariah atau pembiayaan

${ }^{21}$ Adijani al Alabij, dkk., Sengketa Tanah Wakaf di Kalimantan Selatan, Laporan Penelitian, Pusat Penelitian IAIN Antasari Banjarmasin, 1999. syariah. $^{22}$ Topik ini dibahas dalam disiplin ilmu ekonomi dan ilmu hukum. Penulis berkecenderungan bahwa tulisan ini hanya menyinggung aspek hukum ekonomi dan tidak membicarakan aspek ekonominya dikarenakan beberapa hal, yaitu: (1) Praktek hukum ekonomi syariah dengan pelbagai bentuknya sudah sejak lama diperaktekkan oleh orang Banjar. Misalnya dalam bentuk transaksi jual beli, perjanjian dagang, sewamenyewa, gadai, dan lain-lain yang memperhatikan kaidah halal-haram dan pelarangan riba, yang sudah berjalan dalam masyarakat Banjar sejak lama. (2) Pelaksanaan zakat, infak, sedekah, hibah, wasiat, dan kewarisan syariah juga sudah ada, tetapi pada umumnya sebagai hukum diyânî murni dan tidak banyak dalam bentuk hukum qadhầ $\hat{\imath}$, dimana terdapat lembaga penyelesaian sengketa ketika terjadi sengketa atau adanya badan yang bertanggungjawab dalam melaksanakan setiap putusan yang diambil berdasarkan peraturan perundang-undangan yang jelas. (3) Dengan UndangUndang No.3 Tahun 2006 tentang Perubahan atas Undang-Undang No.7 Tahun 1989 tentang Peradilan Agama, maka kesempatan untuk berlakunya hukum ekonomi syariah sebagai hukum qadhầî semakin besar.

Akan tetapi kemudian, di kampung-kampung para petani sudah sering melakukan praktek jual beli hidup untuk menyebut istilah perjanjian jual beli leasing, akad mudhârabah maupun musyarakah. Begitu juga dalam praktek qirâdh pada saat petani mangaronkan ${ }^{23}$ sawahnya kepada seorang penggarap. Bagi hasil ini mirip dengan praktek yang ada pada produk ekonomi syariah sekarang ini.

Persoaloannya adalah ketika terjadi sengketa dagang atau sengketa di bidang ekonomi syariah, lembaga mana yang berwenang menyelesaikan sengketa tersebut. Sehubungan dengan Undang-Undang No. 3 Tahun 2006, maka sengketa bidang ekonomi syariah menjadi kewenangan peradilan agama. Masalahnya adalah bagaimana prospek penyelesaiannya di pengadilan. Hal ini masih terkendala oleh beberapa faktor, antara lain, kesiapan para hakim agama dalam menyambut kewenangan tersebut dan segi peraturan sendiri dianggap masih kurang memadai mengingat belum ada hukum materiil dan formil yang dijadikan acuan, walaupun ada panduan dalam bentuk fatwafatwa Dewan Syariah Nasional (DSN) yang merupakan bentukan MUI. Kemudian secara kelembagaan, budaya

${ }^{22}$ Di negara-negara Islam tidak populer istilah ekonomi syariah, tetapi lebih dikenal dengan istilah ekonomi Islam, misalnya di Malaysia dikenal Islamic Bank, juga di negara-negara Timur Tengah lebih dikenal dengan istilah Islamic Law and Finance.

${ }^{23}$ Akad bagi hasil antara pemilik modal dengan petani atau tukang kebun. 
masyarakat yang belum mendukung kewenangan dan kehadiran ekonomi syariah tersebut. ${ }^{24}$

Saat ini, dengan kehadiran konsep ekonomi syariah maka setiap terjadi sengketa akan diselesaikan melalui lembaga arbitrase syariah nacional. Kalau tidak berhasil, maka akan diselesaikan sesuai dengan kesepakatan akad yang dibuat oleh para pihak, apakah ke Basyarnas atau melalui pengadilan agama.

Di masyarakat Banjar pada masa lalu, dan mungkin masih berlaku sampai masa kini, jika terjadi suatu sengketa, termasuk dalam hal ini yang berkaitan dengan sengketa dagang, maka cenderung diselesaikan melalui adat badamai. Melalui forum ini akan terlihat fungsi dan peran tokoh-tokoh adat atau masyarakat dan tuan guru dalam hal menyelesaikan sengketa (ADR).

\section{Penutup}

Dari uraian tersebut dapat ditarik kesimpulan bahwa orang Banjar merupakan sub-etnis yang mendiami kawasan Kalimantan Selatan, yang menurut para ahli asal usulnya berasal dari Melayu pesisir. Sejak lama mereka bermigrasi dan membentuk koloni di sekitar teluk raksasa Kalimantan Selatan. Perlahan-lahan mereka berinteraksi dan berasimilasi dengan penduduk asli yang akhirnya membentuk sebuah komunitas dalam sebuah kerajaan Banjar. Islam merupakan landasan budaya dan identitas komunitas Banjar.

Orang Banjar sejak dahulu memiliki watak sebagai komunitas pekerja keras, ulet (cangkal), dan gigih dalam berusaha. Mereka berpandangan bahwa hidup merupakan kerja (amal). Hanya melalui amallah seseorang akan mendapatkan penilaian. Etos kerja orang Banjar sangat dipengaruhi oleh ajaran Islam. ${ }^{25}$ Dalam paham keberagaman ini, pandangan Syâfî̀ sangat dominan dalam memberikan warna sikap keberagamaan. Hal ini terlihat dari aspek ibadah maupun akad sebagai simbol dalam pelaksanaan dagang orang Banjar.

Kehadiran konsep ekonomi syariah pada masyarakat Banjar sebenarnya tidak asing lagi, karena nilai-nilai ajaran Islam yang berkaitan dengan prinsip-prinsip dagang atau muamalah sudah sangat akrab dengan budaya Banjar. Kehadiran ekonomi syariah yang

${ }^{24}$ Berbeda dengan Malaysia, kehadiran ekonomi syariah tumbuh dari bawah, ia sudah merupakan hajat dan kebutuhan masyarakat Islam. Tetapi di Indonesia, semuanya, baik dari segi produk atau kelembagaan datang dari atas (top down), tetapi di Malaysia dari bawah (bottom up).

${ }^{25}$ Ahmadi Hasan, Adat Badamai (Studi tentang Bentuk-Bentuk Penyelesaian Sengketa Menurut Budaya Hukum pada Masyarakat Banjar), Laporan Penelitian Individual, Pusat Penelitian IAIN Antasari Banjarmasin, 2003. dipaksakan dari atas (top down) nampaknya sangat relevan dengan adat atau budaya dagang orang Banjar. Adat dagang yang dilandasi nilai-nilai syariah tampaknya sudah memasyarakat, bahkan tumbuh dari bawah (bottom up) pada masyarakat Banjar. Masalahnya adalah seberapa besar dampak adat dagang orang Banjar ini memberikan kontribusi atau sumbangsih dalam perkembangan konsep ekonomi syariah sampai saat ini masih perlu dibahas secara lebih mendalam. []

\section{Pustaka Acuan}

Abdurrahman, Menggagas Format Baru Peranan Peradilan Agama Pasca Lahirnya UU No. 3 Tahun 2006 tentang Peradilan Agama, makalah disajikan dalam Seminar tentang Peranan Peradilan Agama Pasca Lahirnya UU No. 3 tahun 2006 pada tanggal 18 September 2006 di Fakultas Syari'ah IAIN Antasari Banjarmasin.

Alabij, Adijani al, dkk., Sengketa Tanah Wakaf di Kalimantan Selatan, Laporan Penelitian, Pusat Penelitian IAIN Antasari Banjarmasin, 1999.

Arbain, Taufik, Migrasi Orang Banjar di daerah Kalimantan Tengah, Program Kependudukan Universitas Gajah Mada, Yogyakarta, tahun 2003.

-------, Strategi Adaptasi Migrasi Banjar di Palangka Raya Pasca Konflik Dayak-Madura Kalimantan Tengah, Tesis Program Pasca sarjana Universitas Gajah Mada Yogyakarta, Maret, 2004.

Daud, Alfani, Islam dan Masyarakat Banjar: Deskripsi dan Analisa Kebudayaan Banjar, Jakarta: Raja Grafindo Persada, 1997.

Haar, B. Ter, Asas-Asas Hukum Adat, Jakarta: Pradnya Paramitha, 1999.

Hasan, Ahmadi, Adat Badamai (Studi tentang Bentuk-Bentuk Penyelesaian Sengketa Menurut Budaya Hukum pada Masyarakat Banjar), Laporan Penelitian Individual, Pusat Penelitian IAIN Antasari Banjarmasin, 2003.

------, Adat Badamai Interaksi Hukum Islam dengan Hukum Adat pada Masyarakat Banjar, Banjarmasin: Antasari Press, 2007.

J. Jahmin, Lada, Raja dan Pedagang (Perdagangan di Banjarmasin Medio abad 17), Tesis, Sastra Sejarah UGM Yogyakarta, 1991.

Lubis, Suhrawardi K., Hukum Ekonomi Islam, Jakarta: Sinar Grafika, 2000.

Lukito, Ratno, Pergulatan Hukum Islam dan Hukum Adat, Jakarta: Inis, 1998.

Mallinkordt, Het Adaatrecht van Boerneo, Leiden: J.E. Brill, 1928.

Muhammad, Bushar, Asas-Asas Hukum Adat, Sebuah Pengantar, Jakarta: Pradnya Paramitha, 2002. 
Potter, Lesley, Banjarese in and beyond Hulu Sungai, South Kalimantan a study of cultural independence, economic opportunity and mobility in New Challenges in The Modern Economic History OfIndonesia, Edited by J. Thomas Lindblad, Programme of Iindonesian Studies Leiden, 1993.

Saleh, M. Idwar, Banjarmasin Sejarah Singkat mengenai Bangkit dan Berkembangnya Kota Banjarmasin serta Wilayah sekitarnya sampai dengan tahun 1950, Naskah tidak dipublikasikan, 1975.

Soekanto, Soerjono, Hukum Adat Indonesia, Jakarta: Rajawali Press, 1983.

-.-----, Kedudukan dan Peranan Hukum Adat di
Indonesia, Jakarta: Kurnia Esa, 1970.

Sudrajat, Ajat, Etika Protestan dan Kapitalisme Barat, Relevansinya dengan Islam Indonesia, Jakarta: Bumi Aksara, 1994.

Tim Peneliti, Mazhab Fikih yang Berkembang di Kalimantan Selatan, Fakultas Syariah, IAIN Antasari, Banjarmasin, 1990.

Vogel, Frank F. and Samuel L. Hayes, Islamic Law and Finance Religion, Risk, and Return, London: Kluwer Law International, 1998. 